\title{
Program Membaca Ekstensif: Meningkatkan Motivasi Membaca Siswa
}

\section{Extensive Reading Program: Increase the Students' Reading Motivation}

\author{
Dondian Putra ${ }^{1}$, Bachrudin Musthafa ${ }^{2}$, Yanty Wirza ${ }^{3}$ \\ ${ }^{1}$ Guru SMAN 3 Mandau, Kabupaten Bengkalis, Riau, Indonesia \\ ${ }^{2,3}$ Universitas Pendidikan Indonesia, Bandung, Jawa Barat, Indonesia \\ dondputra@upi.edu
}

Naskah diterima tanggal 20/10/2019, direvisi akhir tanggal 20/11/2019, disetujui tanggal 23/12/2019

\begin{abstract}
Abstrak
Penelitian ini bertujuan untuk memverifikasi apakah program membaca ekstensif (extensive reading program) mampu mempromosikan motivasi membaca bahasa Inggris siswa sekolah menengah atas. Kegiatan extensive reading program (ERP) diadakan selama 10 minggu dengan 30 peserta kelas XI yang terdaftar pada tahun ajaran 2019/2020 dari sekolah menengah atas di Riau. Kuisioner individu fokus kemudian dilakukan untuk semua 30 peserta yang dipilih, sampel penelitian ini dipilih melalui metode purposive sampling. Kriteria sampel adalah siswa yang memilih klub bahasa Inggris untuk kegiatan ekstrakurikuler. Data penelitian dikumpulkan melalui penyebaran angket motivasi membaca sebelum dan sesudah implementasi program membaca ekstensif. Kemudian data dianalisis dengan menggunakan uji T berpasangan (Uji T berpasangan) program SPSS 16.0. Temuan mengungkapkan bahwa ada perbedaan yang signifikan antara kuesioner pertama dan kuesioner kedua dari motivasi membaca siswa. Dapat disimpulkan bahwa perbedaan yang signifikan tersebut disebabkan oleh implementasi program membaca ekstensif yang telah dilakukan selama 10 minggu.
\end{abstract}

Kata kunci: Membaca Ekstensif, Program Membaca Luas, dan Motivasi Membaca

\begin{abstract}
The study aims to verify whether extensive reading program (ERP) is able to promote senior high school students' English reading motivation. An ERP activity was held for 10 weeks with 30 participants from senior high schools class XI in Riau who registered in 2019/2020. Focus individual questionnaires were then carried out for all 30 selected participants, the sample of this study selected through purposive sampling method. The criterion of sample was the students who chose the English club for an extracurricular activity. The data of study were gathered through distributed the motivation reading questionnaire before and after the implementation of extensive reading program. Then the data were analyzed by using paired T-test (Uji $T$ berpasangan) the program of SPSS 16.0. The findings reveal that there was a significant difference between the first questionnaire and the second questionnaire of students reading motivation. It can be concluded that the significant difference was caused by implementation of extensive reading program that conducted for 10 weeks.
\end{abstract}

Keywords: Extensive Reading, Extensive Reading Program, and Reading Motivation

\section{PENDAHULUAN}

Membaca tidak hanya memberikan manfaat dalam mengumpulkan informasi dan pengetahuan, tetapi juga dapat meningkatkan keterampilan kosa kata dan "literacy" (melek huruf) dari siswa, mengajari mereka konsep matematika atau sains, membantu mereka belajar sejarah, dan dapat mengajar mereka empati (Rymanowicz, 2017). Para siswa akan memiliki kesempatan untuk memahami cerita 
dari sudut pandang karakter ketika mereka membacanya. Siswa akan mengembangkan pemahaman dan rasa hormat mereka terhadap pengalaman orang lain dengan melakukan latihan melihat dunia melalui dari sudut pandang orang lain.

Ada beberapa manfaat lain dari membaca, seperti membaca memperkuat koneksi otak dan membangun koneksi baru. Membaca adalah tugas yang jauh lebih rumit bagi pikiran manusia daripada kegiatan lain seperti menonton TV. Membaca adalahlatihan terbaik untuk pikiran kita, dan bahkan dapat meningkatkan daya ingat kita (Trombetta, 2017). Sejalan dengan ini, Jager (2017) menyatakan bahwa membaca memberikan kontribusi signifikan terhadap fungsi otak manusia seperti; membaca merangsang otak manusia, mengurangi stres, memperluas kosa kata kita, meningkatkan memori kita, meningkatkan fokus kita, meningkatkan keterampilan menulis, dan mengalihkan perhatian kita dengan cara yang benar.

Membaca tidak lepas dari proses belajar mengajar. Ini adalah salah satu cara untuk mencapai tujuan pengajaran dan pembelajaran nasional. Tujuan dari proses belajar mengajar nasional adalah untuk menghasilkan individu yang mencapai pengetahuan faktual, konseptual, dan prosedural dalam sains, teknologi, seni, dan budaya dengan wawasan kemanusiaan, kebangsaan, dan peradaban sebagaimana tercantum dalam Peraturan Menteri Pendidikan dan Kebudayaan nomor 54 tahun 2013 (Permendikbud, 2013). Semua tujuan itu tidak akan tercapai tanpa adanya proses membaca dari peserta didik dan pendidik.

Salah satu tujuan utama dari kurikulum 2013 adalah untuk membangun karakter siswa dengan meningkatkan keterampilan membaca siswa yang dikenal dengan literasi. Kegiatan literasi ini dikembangkan berdasarkan Peraturan Menteri Pendidikan dan Kebudayaan nomor 21 tahun 2015 (Permendikbud, 2015). Melalui kegiatan literasi ini diharapkan generasi Indonesia mendatang menjadi generasi literasi. Namun itu tidaklah mudah untuk merubah kebiasaan sebuah bangsa yang sebelumnya tidak mempunyai budaya baca yang tinggi, itu memerlukan perjuangan dan kerja keras dari pemerintah dalam hal ini departemen pendidikan, dinas pendidikan, sekolah, guru, dan orang tua. Untuk mewujudkan itu juga diperlukan sebuah metode yang bisa menarik minat baca dari peserta didik supaya mereka tertarik untuk membaca.

Extensive reading (membaca ekstensif) adalah sebuah metode yang dinilai oleh banyak orang sebagai sebuah metode yang bagus dalam meningkatkan minat baca siswa. Penelitian mengenai extensive reading dalam pengajaran bahasa Inggris sebagai bahasa asing dan bahasa kedua juga banyak dilakukan, terutama pada tingkat universitas atau perguruan tinggi.

Dalam hal ini peneliti akan mengimplementasikan sebuah program membaca ekstensif dalam bahasa Inggris terhada siswa kelas XI SMA. Penelitian ini bertujuan menginvestigasi perubahan motivasi membaca siswa dalam bahasa Inggris sebagai bahasa asing dengan menerapkan extensive reading program bagi siswa sekolah menengah atas. Pertanyaan penelitiannya adalah; Apakah program membaca ekstensif memberikan pengaruh yang signifikan terhadap motivasi membaca siswa?

\subsection{Hakekat dari membaca ekstensif}

Membaca ekstensif adalah teknik dalam pengajaran membaca yang didefinisikan sebagai situasi di mana siswa membaca banyak materi pada level membaca mereka dalam sebuah bahasa yang baru. Tujuan mereka membaca untuk umum, untuk makna secara keseluruhan, dan untuk informasi sekaligus dengan kesenangan (Day \& Bamford, 2004). Itu diproyeksikan untuk membangun sikap positif terhadap membaca, untuk mengembangkan kebiasaan membaca yang baik, untuk membangun kosa kata dan struktur pengetahuan (Richards \& Schmidt, 2010).

Konsep membaca ekstensif adalah mengekspos siswa ke lingkungan yang kaya input dan menyenangkan, dengan maksud bahwa pengetahuan bahasa mereka akan meningkat dan antusiasme mereka untuk 
belajar akan berkembang secara alami (Sheu, 2003).

Dalam proses pembelajaran, guru mengambil peran penting yaitu tetap menjadi motivasi siswa dan menciptakan motivasi dalam diri siswa secara bertahap jika tidak ada (Harmer, 2007). Selain itu, peran guru dalam program membaca yang luas adalah untuk mengembangkan siswa sebuah minat seumur hidup dalam membaca dan penerapannya dalam kehidupan sehari-hari mereka (Sachs, 2001).

Ada sepuluh karakteristik atau prinsip membaca ekstensif sebagai pendekatan atau prosedur pengajaran/pembelajaran bahasa, yang telah diidentifikasi sebagai faktor kunci dalam keberhasilan program membaca ekstensif. Day \& Bamford (2004) mengatur kompleksitas pendekatan membaca yang luas yang mungkin paling jelas dalam deskripsi karakteristiknya dalam bentuk sepuluh prinsip utama untuk mengajar bacaan luas; (1) Materi bacaan yang mudah; (2) ketersediaan berbagai bahan bacaan tentang berbagai topik; (3) Siswa atau pembaca bisa memilih sendiri sumber bacaan sendiri sesuai dengan keinginan masing-masing; (4) Membaca sebanyak mungkin; (5) Kecepatan membaca biasanya lebih cepat; (6) Tujuan membaca biasanya terkait dengan kesenangan, informasi, dan pemahaman umum; (7) Membaca secara individual dan diam/sunyi; (8) Membaca adalah ganjarannya sendiri; (9) Guru mengorientasikan dan membimbing siswa mereka; dan (10) Guru adalah panutan pembaca.

Tujuan dari membaca ekstensif adalah untuk memperoleh pemahaman umum dengan berfokus secara umum pada makna dari apa yang sedang dibaca dari pada bahasa dengan meningkatkan kecepatan membaca dan jumlah sumber bacaan atau membaca lebih luas (Carrell \& Carson, 1997).

\subsection{Program membaca ekstensif (extensive reading program).}

Program membaca ekstensif di sini adalah sebuah program dalam pengajaran membaca bahasa Inggris sebagai bahasa asing yang berdasarkan kepada karakteristik atau prinsip membaca ekstensif sebagai pendekatan atau prosedur pengajaran/ pembelajaran bahasa. Pada program membaca ini kesepuluh dari karakter dan prinsip tersebut akan dijadikan patokan dalam menjalankan program tersebut. Seperti dijelaskan sebelumnya bahwa program ini diimplementasikan di salah satu sekolah menengah atas di provinsi Riau.

Pada kegiatan pengajaran program ini merujuk pada buku karangan Day \& Bamford (2004) yang berjudul extensive reading activities for teaching language dari berbagai macam kegiatan pembelajaran membaca yang ada pada buku tersebut di implementasikan kedalam tiga kelompok kegiatan; kegiatan sebelum membaca (prereading activities), kegiatan disaat membaca (whilst-reading activities), dan kegiatan setelah membaca (post-reading activities).

Sebelum melakukan program membaca ekstensif hendaknya harus direncanakan dengan baik dan fleksibel. Jika tidak, maka bisa gagal karena kurangnya arah tujuan, sumber daya yang tidak memadai, kehilangan bahan bacaan, atau penurunan antusiasme secara umum. Dalam menyiapkan program membaca ekstensif, beberapa aspek harus dipertimbangkan agar menjamin bahwa program yang dikelola dengan cara yang efektif dan positif untuk berhasil. Oleh karena itu, setelah berkenalan dengan aspek-aspek teoretis dari membaca ekstensif, para guru harus membuat keputusan tentang beberapa masalah yang lebih praktis: bagaimana mengatur dan mengelola perpustakaan, bagaimana mengelola program, dan kegiatan kelas apa yang cocok untuk memotivasi siswa untuk membaca.

\subsection{Motivasi membaca siswa}

Perilaku gemar membaca dapat ditingkatkan dengan adanya prasyarat minat atau keterkaitan berupa adanya dorongan motivasi yang kuat, sehingga hal tersebut memungkinkan munculnya perilaku membaca dan lebih lanjut lagi apabila aktivitas membaca dilakukan secara terusmenerus akan tumbuh suatau kebiasaan gemar membaca (Krashen, 1996). Motivasi ini dipengaruhi salah satunya oleh faktor internal seseorang. 
Motivasi diri individu, dapat diartikan juga sebagai motif individu dalam melakukan kegiatan membaca, karena memang semua tingkah laku manusia dalam melakukan sesuatu dilandasi adanya motif tertentu. Motif dan motivasi membaca ini didefinisikan hampir sama yaitu penggerak individu dalam melakukan kegiatan membaca. Motivasi yang ada pada diri individu mewakili proses-proses psikologikal, sehingga menyebabkan timbulnya sikap antusias dan persistensi kegiatan-kegiatan sukarela yang ditujukan ke arah pencapaian tujuan, dalam hal ini untuk mencapai perilaku gemar membaca (Sugihartati, 2010). Selain itu membaca lebih dari sekedar memenuhi mood (keinginan) melainkan bagi sebagian orang merasakan membaca merupakan bagian dari proses berimajinasi yang mampu melepas dari depresi dan bisa menimbulkan perasaan tertentu yang membuat pembaca lebih semangat dalam melakukan hal yang diimajinasikan (Usherwood \& Toyne, 2002).

\section{METODE PENELITIAN}

\subsection{Populasi dan sampel}

Desain dari penelitian ini adalah sebuah penelitian kuatitatif yang pengolahan datanya menggunakan bantuan SPSS 16.0. Penelitian ini dilakukan untuk mengetahui respons siswa terhadap penerapan program membaca ekstensif dari segi motivasi membaca siswa. Sampel dari penelitian ini adalah siswa SMAN 3 Mandau Kabupaten Bengkalis Provinsi Riau sebanyak 30 orang yang dipilh melalui metode purposive sampling. Kriteria dari siswa adalah bagi mereka yang memilih english club sebagai program extrakurikuler dari siswa kelas XI untuk tahun pelajaran 2019/2020. Partisipan dari penelitian ini adalah siswa Sekolah Menengah Atas kelas XI (SMAN 3 Mandau Kabupaten Bengkalis Provinsi Riau) dengan julah sebanyak 30 orang dengan rincian lakilaki sebanyak 13 dan perempuan sebanyak 17 orang.

\subsection{Instrumen}

Instrumen yang digunakan dalam penelitian ini adalah sebuah kuisioner motivasi membaca yang terdiri dari 53 item. Kuesioner ini dirancang untuk menilai 11 aspek motivasi membaca yang berbeda. Motivation for Reading Questionnaires (MRQ) yang dikembangkan oleh Wigfield \& Guthrie (1997) yang dibagikan kepada seluruh siswa. Tujuan dari kuesioner ini adalah untuk mengukur berbagai dimensi atau aspek motivasi membaca siswa. Ini juga dapat digunakan untuk menemukan sifat motivasi anak-anak untuk membaca, serta untuk mengetahui apakah ada perubahan pada motivasi siswa antara sebelum dan sesudah pelaksanaan program membaca ekstensif kalau ada seberapa jauh.

Tabel 1. Framework kuisioner motivasi membaca

\begin{tabular}{|c|c|c|c|}
\hline \multirow{2}{*}{ No } & \multirow{2}{*}{ Aspects } & \multicolumn{2}{|c|}{ Item Number } \\
\hline & & Positive & Negative \\
\hline 1 & Reading Efficacy (3 items) & $1,2,3$ & \\
\hline 2 & Reading Challenge (5 items) & $4,5,6,7,8$ & \\
\hline 3 & Reading Curiosity (6 items) & $9,10,11,12,14$ & 13 \\
\hline 4 & Reading Involvement (6 items) & $15,16,17,18,19,20$ & \\
\hline 5 & Importance of Reading (2 items) & 21,22 & \\
\hline 6 & $\begin{array}{l}\text { Reading Work Avoidance } \\
\text { (4 items) }\end{array}$ & & $23,24,25,26$ \\
\hline 7 & Competition in Reading (6 items) & $27,28,29,30,31,32$ & \\
\hline 8 & Recognition for Reading (5 items) & $33,34,35,36,37$ & \\
\hline 9 & Reading for Grades (4 items) & $38,39,40,41$ & \\
\hline 10 & $\begin{array}{l}\text { Social Reasons for Reading } \\
\text { (7 items) }\end{array}$ & $42,43,44,45,46,47,48$ & \\
\hline 11 & Compliance (5 items) & $49,50,51,52,53$ & \\
\hline
\end{tabular}


Pada tabel 1, Kuesioner didistribusikan kepada siswa dua kali. Kuisioner pertama dibagikan pada pertemuan pertama atau sebelum program membaca ekstensif dilaksanakan. Kuisioner kedua dibagikan pada pertemuan terakhir atau akhir dari program membaca ekstensif atau pada pertemuan ke sepuluh. Siswa menjawab setiap item dalam skala 1 sampai 4, dengan $1=$ sangat berbeda dari saya, $2=$ sedikit berbeda dari saya, 3 = sedikit seperti saya, dan 4 = banyak seperti saya.

Pada tabel 2, program membaca ekstensif berlangsung selama sepuluh kali pertemuan, satu kali pertemuan dalam seminggu. Program membaca ekstensif dilaksanakan setiap hari sabtu, di luar jam pelajaran sekolah. Timeline penelitiannya sebagimana dijadwalkan sebagai berikut.

Tabel 2. Waktu pelaksanaan program

\begin{tabular}{|c|c|c|c|}
\hline No & Meeting & Day and Date & Activities \\
\hline 1 & I & Sabtu, 20 July 2019 & $\begin{array}{l}\text { - Membagikan kuisioner pertama kepada siswa dan } \\
\text { minta untuk menjawabnya di tempat. } \\
\text { - Menjelaskan tentang membaca ekstensif kepada siswa }\end{array}$ \\
\hline 2 & II & Sabtu, 27 July 2019 & $\begin{array}{l}\text { - Mulai melaksanakan program dengan menjelaskan } \\
\text { sumber bacaan yang disediakan } \\
\text { - Siswa dipersilakan meilih jenis dan level bacaan yang } \\
\text { diinginkannya. }\end{array}$ \\
\hline 3 & III & Sabtu, 3 Agustus 2019 & Kegiatan kelas \\
\hline 4 & IV & Sabtu, 10 Agustus 2019 & Kegiatan kelas \\
\hline 5 & $\mathrm{~V}$ & Sabtu, 24 Agustus 2019 & Kegiatan kelas \\
\hline 6 & VI & Sabtu, 31 Agustus 2019 & Kegiatan kelas \\
\hline 7 & VII & Sabtu, 7 September 2019 & Kegiatan kelas \\
\hline 8 & VII & Sabtu, 14 September 2019 & Kegiatan kelas \\
\hline 9 & IX & Rabu, 18 September 2019 & Kegiatan kelas \\
\hline 10 & $\mathrm{X}$ & Rabu, 25 September 2019 & $\begin{array}{l}\text { Membagikan kuisioner kedua kepada siswa dan minta } \\
\text { untuk menjawabnya di tempat. }\end{array}$ \\
\hline
\end{tabular}

\section{HASIL DAN PEMBAHASAN}

\subsection{Hasil}

Data dari kuesioner diperiksa menggunakan teknik analisis kuantitatif, khususnya analisis statistik. Tanggapan yang diberikan oleh responden dihitung untuk frekuensi per item pertanyaan dan dikonversi menjadi persentase. Tanggapan-tanggapan itu kemudian dirangkum. Semua tanggapan yang dianalisis kemudian digunakan untuk melaporkan motivasi siswa dan untuk memberikan dukungan pada temuan penelitian.

Data yang dikumpulkan dianalisis dengan program SPSS yang bertujuan untuk mengungkapkan perbedaan yang signifikan antara kuesioner pertama dan kedua dari siswa kemudian digunakan untuk menjawab pertanyaan penelitian secara kuantitatif. Respons siswa terhadap kuesioner diberi kode dan dimasukkan ke dalam program
SPSS 16.0 untuk analisis statistik. Analisis data kuantitatif dan rata-rata nilai dihitung. Dalam analisis statistik yang digunakan dalam penelitian, tingkat signifikansi diterima menjadi 0,05. Setelah mendapatkan skor post-test, ada beberapa tes yang dilakukan termasuk uji distribusi normalitas dan paired t-test.

\section{Uji Normalitas Distribusi}

Tujuan dari uji normalitas adalah untuk melihat apakah data terdistribusi secara normal. Dalam tabel 3. SPSS 16.0, Shapiro-Wilk digunakan untuk menganalisisnya. Pertama-tama level alpha 0,05 dinyatakan. Kedua, distribusi data dianalisis menggunakan Uji Shapiro-Wilk. Terakhir, hasilnya Asymp. Sig dibandingkan dengan tingkat signifikansi. Ini untuk menguji hipotesis. Ketika Asymp sig lebih dari tingkat signifikansi alfa, hipotesis diterima. Ini berarti bahwa data terdistribusi secara 
normal. Kriteria untuk pengujian hipotesis pengujian ini adalah sebagai berikut:

a. H0 dipertahankan jika $\mathrm{p}>\alpha$

b. H1 ditolak jika $\mathrm{p} \leq \alpha$ c. H0: populasi berdistribusi normal

d. H1: populasi bukan distribusi normal

e. P: probabilitas

f. $\alpha$ : tingkat signifikansi

Tabel 3. Uji normalitas

\begin{tabular}{lcccccc}
\hline \multicolumn{7}{c}{ Tests of Normality } \\
\hline \multicolumn{7}{c}{ Kolmogorov-Smirnov ${ }^{a}$} \\
Statistic & $d f$ & Sig. & Statistic & df & Sig. \\
\hline The 1st Questionnaire & .119 & 30 & $.200^{*}$ & .945 & 30 & .126 \\
\hline The 2nd Questionnaire & .170 & 30 & .026 & .903 & 30 & .010 \\
\hline a. Lilliefors Significance Correction & & & & \\
\hline *. This is a lower bound of the true significance.
\end{tabular}

\section{Uji-T berpasangan}

Hasil dari uji normalitas kedua skor (pre-test dan post-test) menunjukkan bahwa data terdistribusi normal dan parametrik. Maka untuk menguji signifikansi perbedaan antara dua skor tersebut digunakan Uji-t berpasangan (Paired T-test). Tujuannya adalah untuk mengukur perbedaan yang signifikan antara pre-test dan post-test dengan tingkat signifikansi pada 0,05 . Uji-t berpasangan (Paired T-test) adalah uji perbedaan parametrik pada dua data berpasangan. Tes ini dimaksudkan untuk tes yang berbeda atau tes komparatif. Uji-t berpasangan akan membandingkan perbedaan dalam MEAN atau rata-rata dua kelompok berpasangan. Pasangan ini berarti sumber data berasal dari subjek yang sama. Kriteria untuk pengujian hipotesis adalah sebagai berikut:

- H0: Tidak ada perbedaan rata-rata antara hasil kuesioner pertama dan skor kuesioner kedua. Ini berarti, tidak ada pengaruh yang signifikan terhadap motivasi siswa untuk membaca dengan menerapkan program membaca ekstensif.

- Ha: Ada perbedaan rata-rata antara hasil kuesioner pertama dan skor kuesioner kedua. Ini berarti, ada pengaruh yang signifikan terhadap motivasi siswa untuk membaca dengan menerapkan program membaca ekstensif.

Pedoman untuk membuat keputusan uji-t berpasangan didasarkan pada nilai signifikansi (Sig.) Output dari SPSS (Santoso, 2014) sebagai berikut:

- Jika Sig. (2-tailed) lebih kecil dari $(<)$ tingkat signifikansi 0,05 , itu berarti ada perbedaan yang signifikan antara variabel pertama dan yang terakhir. Ini menunjukkan bahwa ada pengaruh signifikan yang disebabkan oleh program membaca ekstensif.

- Jika Sig. (2-tailed) lebih besar dari (>) tingkat signifikansi pada 0,05 , itu berarti tidak ada perbedaan yang signifikan antara variabel pertama dan terakhir. Ini menunjukkan bahwa tidak ada pengaruh signifikan yang disebabkan oleh program membaca ekstensif.

Tabel 4. Uji sampel berpasangan

\begin{tabular}{|c|c|c|c|c|c|c|c|c|c|}
\hline \multicolumn{10}{|c|}{ Paired Samples Test } \\
\hline & & \multicolumn{5}{|c|}{ Paired Differences } & \multirow{3}{*}{$t$} & \multirow{3}{*}{$d f$} & \multirow{3}{*}{$\begin{array}{c}\text { Sig. } \\
\text { (2-tailed) }\end{array}$} \\
\hline & & \multirow[t]{2}{*}{ Mean } & \multirow[t]{2}{*}{$\begin{array}{c}\text { Std. } \\
\text { Deviation }\end{array}$} & \multirow[t]{2}{*}{$\begin{array}{c}\text { Std. Error } \\
\text { Mean }\end{array}$} & \multicolumn{2}{|c|}{$\begin{array}{c}\text { 95\% Confidence } \\
\text { Interval of the } \\
\text { Difference }\end{array}$} & & & \\
\hline & & & & & Lower & Upper & & & \\
\hline $\begin{array}{c}\text { Pair } \\
1\end{array}$ & $\begin{array}{c}\text { The } 1^{\text {st }} \\
\text { Questionnaire } \\
\quad- \\
\text { The } 2^{\text {nd }} \\
\text { Questionnaire }\end{array}$ & $-6.45000 \mathrm{E} 1$ & 28.46141 & 5.19632 & -75.12766 & -53.87234 & -12.413 & 29 & .000 \\
\hline
\end{tabular}


Tabel output dari tabel 4 berpasangan di atas menggambarkan nilai Sig. (2 tailed) adalah $0,000<0,05$. Nilai sig.(2-tailed) lebih kecil dari nilai level konfidensi. Ini berarti $\mathrm{H} 0$ ditolak dan Ha diterima. Ini menunjukkan bahwa ada perbedaan yang signifikan secara statistik antara hasil kuesioner pertama dan kuesioner kedua pada motivasi siswa untuk membaca. Dapat disimpulkan bahwa perbedaan tersebut diakibatkan oleh penerapan program membaca ekstensif sebagaimana ditentukan secara statistik oleh uji t berpasangan (Paired T-test).

Cara lain untuk menguji perbedaan yang signifikan adalah berdasarkan table $\mathrm{t}(\mathrm{T}$ table), dengan membandingkan hasil T-test dengan table $\mathrm{T}$ melalui rumusan keputusan berikut:

- Jika t hitung $\leq \mathrm{t}$ table maka H0 diterima dan Ha ditolak

- Jika thitung $>\mathrm{t}$ table Ha diterima dan H0 ditolak

Maka dapat diuraikan sebagi berikut, berdasarkan table 4 diatas nilai t hitung adalah 12.413 kemudian dicari nilai untuk df 29 pada level konfidensi 0.05 pada t tabelnya adalah sebesar 2.000. Maka 12.413>2.000, nilai $t$ hitung lebih besar dari nilai table t. Jadi dapat dikatakan bahwa $\mathrm{Ha}$ diterima dan $\mathrm{H} 0$ ditolak. Artinya ada perbedaan ratarata antara hasil kuisioner pertama dan skor kuisioner kedua. Ini berarti, ada pengaruh yang signifikan terhadap motivasi siswa untuk membaca dengan menerapkan program membaca ekstensif.

Untuk uraian lebih rinci maka hasil motivasi siswa untuk membaca kuisioner juga dijelaskan berdasarkan konstruksi motivasi membaca. Sebagaimana dinyatakan dalam bagian instrumen, ada sebelas konstruksi yang termasuk dalam kuesioner ini, yaitu pada tabel 5 sebagai berikut.

Tabel 5. Skor dari kuisioner motivasi membaca siswa

\begin{tabular}{clcccc}
\hline \multirow{2}{*}{ No } & \multirow{2}{*}{ Constructions } & \multicolumn{2}{c}{ Scores } & \multirow{2}{*}{ Range } & \% \\
\cline { 3 - 4 } & & $\mathbf{Q 1}$ & $\mathbf{Q 2}$ & & \\
\hline 1 & Reading Efficacy & 150 & 263 & 113 & 1.8 \\
2 & Reading Challenge & 274 & 449 & 175 & 2.8 \\
3 & Reading Curiosity & 315 & 496 & 181 & 2.8 \\
4 & Reading Involvement & 316 & 533 & 217 & 3.4 \\
5 & Importance of Reading & 114 & 169 & 55 & 0.9 \\
6 & Reading Work Avoidance & 225 & 337 & 112 & 1.8 \\
7 & Competition in Reading & 332 & 506 & 174 & 2.7 \\
8 & Recognition for Reading & 254 & 420 & 166 & 2.6 \\
9 & Reading for Grades & 212 & 345 & 133 & 2.1 \\
10 & Social Reasons for Reading & 367 & 577 & 210 & 3.3 \\
11 & Compliance & 271 & 437 & 166 & 2.6 \\
\hline & TotaL & $\mathbf{2 , 8 3 0}$ & $\mathbf{4 , 5 3 2}$ & $\mathbf{1 , 7 0 2}$ & $\mathbf{2 6 . 8}$ \\
\hline Q1 & The first questionnaire & & & & \\
Q2 & The second questionnaire & & & &
\end{tabular}

\subsection{Pembahasan}

Sebagaimana dinyatakan dalam temuan data, data motivasi membaca siswa juga dianalisis secara statistik dengan menggunakan SPSS 16.0. Tujuan pengukuran ini adalah untuk mengungkapkan apakah ada perbedaan yang signifikan dalam motivasi membaca siswa antara sebelum dan sesudah implementasi program membaca ekstensif. Hasil dari analisis statistik Sig. (2-tailed) adalah 0,000. Ini menunjukkan bahwa $\mathrm{H} 0$ ditolak dan Ha diterima dengan sig. (2-tailed) $<0,05$. Ada perbedaan rata-rata antara hasil kuesioner pertama dan kuesioner kedua. Ini berarti bahwa ada pengaruh yang signifikan terhadap pergeseran motivasi membaca siswa yang disebabkan oleh penerapan program membaca yang luas.

Hasilnya juga tetap sama apabila disbandingkan hasil nilai $\mathrm{t}$ dengan $\mathrm{t}$ table. 
Nilai t hitung besar dari nilai t table. Nilai $\mathrm{t}$ hitung adalah 14.221 sementara nilai $\mathrm{t}$ table adalah 2.000. Apabila dibandingkan keduanya maka dapat disimpulkan bahwa nilai t hitung 14.221 lebih besar dari nilai $t$ table 2.000 .

Tabel 5 Skor dari kuisioner motivasi membaca siswa menunjukkan jumlah perubahan motivasi membaca siswa antara sebelum dan sesudah implementasi program secara keseluruhan adalah $26,8 \%$ dari total skor kuisioner sebelumnya 2.830 naik menjadi 4,532 dengan range sebesar 1.702. Dari table diatas dapat digambarkan bahwa seluruh komponen dari kuisioner motivasi membaca siswa mengalami kenaikan setelah pelaksanaan program membaca ekstensif. Peningkatan yang paling banyak terjadi pada komponen no 4 yaitu keterlibatan membaca (reading involvement) sekitar $3.4 \%$ dari kuisioner pertama sebanyak 316 menjadi 5.33. Peningkatan yang paling sedikit terjadi pada komponen no 5 pentingnya membaca (importance of reading) hanya $0.9 \%$ dari 114 kuisioner pertama menjadi 169 pada kuisioner kedua dengan range sebesar 55.

Terkait dengan reading efficacy, Laen \& Paulshock (2018) juga telah melakukan penelitian dan mereka sealigus membuktikan bahwa reading efficacy seseorang bisa ditingkatkan melalui membaca yang banyak dengan memberikan target kata yang harus dicapai dalam kurun waktu tertentu.

Mereka membandingkan tiga kelompok mahasiswa dengan pemberian metode yang berbeda untuk meningkatkan jumlah membaca dan membaca self-efficacy di antara peserta didik L2. (1) Mereka meminta grup dengan member target kata untuk dibaca setidaknya 2.500 kata seminggu di luar kelas; (2) Mereka meminta kelompok membaca sunyi berkelanjutan untuk melakukan (a) di kelas SSR selama 15 menit setiap minggu, dan (b) membaca satu buku per minggu; (3) Mereka meminta kelompok pembanding untuk membaca satu buku per minggu. Pada periode pasca pemberian metode, semua peserta wajib untuk membaca satu buku per minggu di luar kelas, dan hasilnya kelompok yg selalu diberikan target kata membaca lebih banyak secara signifikan, dibandingkan dengan baseline yang telah ditetapkan sebelumnya. Mereka berpendapat bahwa peserta didik dalam kelompok target kata menginternalisasi motivasi ekstrinsik dari kata-target, dan ini mengarahkan mereka untuk melakukan lebih banyak membaca gratis dan meningkatkan kemanjuran diri membaca mereka lebih dari kelompok lain.

Pada komponen kedua digambarkan ada kenaikan motivasi membaca siswa dengan adanya beberapa tantangan dalam membaca seperti pada tabel 5 tantangan membaca (reading challenge) meningkat menjadi $2.8 \%$ dari 274 menjadi 449 dengan selisih 175. Itu menggambarkan bahwa tantangan yang diberikan kepada mereka bisa meningkatan motivasi mereka dalam membaca. Ini juga berarti bahwa sebagian besar dari siswa sejalan dengan konsep yang menantang dan berfungsi sebagai factor tambahan dari membaca. Lebih menarik untuk dipelajari sejauh mana dan dalam bentuk apa tantangan yang efektif untuk memotivasi siswa dipertanyakan karena tidak dibahas dalam penelitian ini.

Keingintahuan membaca siswa (reading curiosity), berdasarkan analisis data, meningkat sebanyak $2.8 \%$ dengan skor sebelum implementasi program sebanyak 315 dan skor tersebut naik sebanyak 181 seiring berjalannya program membaca ekstensif tersebut. Pada saat kuisioner kedua skornya menjadi 496.

Ini menunjukkan kenaikannya signifikan dalam meningkatkan motivasi membaca siswa dan siswa atau responden berada dalam posisi mendukung bahwa rasa ingin tahu adalah faktor penentu dalam meningkatkan motivasi membaca mereka. Tanggapan terhadap fenomena seperti itu Hill, et al (2016) menegaskan bahwa memberikan informasi yang moderat akan meningkatkan rasa ingin tahu konsumen. Temuan ini menunjukkan implikasi potensial pada cara bagaimana instruktur bahasa Inggris meningkatkan keingintahuan siswa dalam membaca bahasa Inggris.

Keterlibatan membaca (reading involvement) mengacu pada kenikmatan 
yang terlibat dengan membaca berbagai jenis teks, motivasi intrinsik (Deci \& Ryan, 1985). Selanjutnya, Torres (2010) melaporkan bahwa memberikan pilihan kepada siswa dan memungkinkan diskusikelompokmemotivasi siswa untuk membaca. Menanggapi tentang keterlibatan siswa dalam membaca, dapat dilihat pada table 5 menunjukkan bahwa ada kenaikan sebesar 3.4\% dan ini merupakan kenaikan paling tinggi diantara semua konstruksi kuisioner motivasi membaca. Skor awal sebelum pelaksanaan program sebanyak 316 selanjutnya pada kuisioner kedua skornya naik menjadi 533, terjadi kenaikan skor sebanyak 217. Maka dapat disimpulkan kenaikan itu diakibatkan oleh keterlibatan membaca siswa selama dalam implementasi program membaca ekstensif tersebut.

Selanjutnya peningkatan yang paling sedikit terjadi pada konstruksi pentingnya membaca (importance of reading) sebanyak $0.9 \%$ atau hanya naik sebanyak 55 dari skor awal sebanyak 114 dan menjadi 169 pada skor kuisioner kedua. Itu juga menandakan bahwa siswa belum menyadari pentingnya membaca. Motivasi mereka untuk membaca masih didominasi oleh factor-faktor yang lain.

Membaca menghindari pekerjaan (reading work avoidance) seperti diuraikan sebelumnya untuk pertanyaan pada konstruksi ini adalah sifatnya negative jadi penilaiannya dibalikkan dari pertanyaan lain. (Lihat Tabel 1. Framework kuisioner motivasi membaca). Pada bagian ini juga terjadi peningkata motivasi siwa dalm membaca dari skor 225 menjadi 337, terjadi peningkatan sebesar 112 $(1.8 \%)$.

Di sisi lain, penghindaran adalah tindakan untuk menghindari situasi yang mengancam, budaya semua manusia (Holtforth, 2008). Dalam hal ini, itu adalah tindakan untuk menghindari skor buruk dalam penulisan bahasa Inggris, hukuman dari guru bahasa Inggris, dll. Menurut Krypotos, et al (2015) penghindaran adalah karakteristik utama dari rasa takut adaptif dan maladaptif. Persepsi siswa tentang penghindaran adalah bahwa mereka membaca bukanlah untuk menghindari sesuatu yang tidak mereka sukai, sesuatu yang ditakui ataupun sesuatu yang mengancam mereka. Itu dapat dilihat dengan peningkatan motivasi mereka untuk mebaca pada bagian ini.

Kompetisi dalam membaca (competition in reading) kompetisi dalam membaca merupakan kompetisi tingkat dasar memanifestasikan dalam persaingan (Mayo, 2016). Menurut dia tindakan yang bersaing, dalam bisnis, dimaksudkan untuk mengamankan pelanggan pelindung. Dalam hal ini, ada kebutuhan untuk mendefinisikan konsumen untuk memiliki implikasi yang dapat diterima pada membaca. Dalam konteks yang berbeda, Chumacero, et al (2016) melaporkan bahwa kompetisi memiliki dampak pendidikan yang positif, signifikan secara statistik, dan relevan secara ekonomi pada sekolah swasta dan negeri mengkonfirmasi urgensi kompetisi. Pada konstruksi ini peningkatan motivasi membaca siswa juga signifikan yaitu $2.7 \%$ atau terjadi peningkatan sebesar 174 dari skor kuisioner pertama 332 menjadi 506.

Pengakuan untuk membaca (recognition for reading), pengakuan membaca adalah keinginan prestasi pembaca bahasa untuk diakui oleh guru atau teman sebaya. Alasan dasar adalah argumen Honneth (1995) seperti yang diyakini oleh Huttunen \& Heikkinen (2004) bahwa manusia memerlukan pengakuan antar-subjektif atas kemampuan dan pencapaian mereka. Pada bagian ini juga terjadi peningkatan motivasi membaca siswa sebanyak 166 (2.6\%) dari 254 menjadi 420.

Selain itu, membaca untuk nilai (reading for grades) juga dianggap sebagai faktor motivasi tambahan lainnya. Siswa termotivasi untuk membaca demi mencapai nilai yang baik (Wang \& Guthrie, 2011). Skor pada kuisioner pertama sebanyak 212 dan meningkat sebanyak $133(2.1 \%)$ pada kuisioner kedua.

Alasan sosial untuk membaca (social reasons for reading) merupakan peningkatan terbanyak nomor dua setelah keterlibatan membaca. Siswa mengalami peningkatan motivasi mereka sebanyak 210 (3.3\%) dari 
skor awala sebanyak 367 menjadi 577.

Forgas, et al (2005) berpendapat bahwa perilaku sosial dan penilaian adalah perilaku dan penilaian yang termotivasi. Ini menyiratkan alasan sosial untuk membaca mengatur motivasi pembaca bahasa.

Karya Sappington, Kinsey, dan Munsayac (2002) dapat digunakan untuk membahas temuan kepatuhan membaca dan membaca, menurut mereka, memungkinkan untuk menunjukkan hubungan antara persiapan membaca dan keberhasilan berikutnya pada ujian akhir. Berbeda dari laporan Sharma, et al (2013) tentang penilaian keputusan kepatuhan membaca di kalangan mahasiswa sarjana yang secara khusus melaporkan faktor-faktor yang mempengaruhi keputusan siswa untuk mematuhi pembacaan kursus yang ditugaskan.peningkata yang signifikan juga terjadi pada konstruksi ini dengan 166 (26.8\%) dari skor awalnya 271 menjadi 437.

Seiring dengan apa yang dikatakan oleh Martini (2008) bahwa secara keseluruhan kegiatan membaca ekstensif telah sukses meningkatkan motivasi membaca siswa. Berdasarkan penelitiannya Martini (2008) mengemukakan temuan yang utama antara lain:

a. Banyak dari siswa menikmati membaca text berbahasa inggris karena tidak sulit dan topiknya menarik.

b. Banyak dari siswa tertarik membaca dalam bahasa inggris karena siswa sendiri yang memilih topicnya menurut kesukaan mereka sendiri.

c. Sebagian besar siswa tertarik membaca teks bahasa Inggris karena mereka ingin meningkatkan kemampuan membaca, pengetahuan umum, dan mendapatkan banyak informasi dan berita aktual dari buku, majalah, surat kabar, dan internet.

d. Sebagian besar siswa tertarik untuk membaca teks bahasa Inggris karena mereka tidak harus menggunakan kamus. Dengan kata lain, dengan membaca banyak teks bahasa Inggris, mereka telah dilatih untuk memberi makna pada katakata yang tidak dikenal.

e. Sebagian besar siswa suka membaca teks bahasa Inggris untuk mendapatkan kesenangan.

f. Akhirnya, dapat diringkas bahwa tugas membaca ekstensif telah berhasil memecahkan masalah siswa dalam meningkatkan kemampuan membaca mereka. Dengan kata lain, Tugas Membaca Luas dapat meningkatkan motivasi membaca siswa.

Nishino (2007) dan de Burgh-Hirabe (2011) juga mengidentifikasi pengaruh ini. Realisasi pencapaian yang dirasakan para siswa Nishino begitu mereka dapat membaca pembaca yang dinilai dalam bahasa Inggris dengan nyaman, memotivasi mereka untuk melangkah lebih jauh, dan terus membaca materi otentik. Siswa dalam penelitian De Burgh-Hirabe (2011) lebih suka pembaca yang dinilai untuk buku anak-anak otentik dalam bahasa Jepang. Namun, mereka juga menyatakan puas melihat mereka membuat kemajuan, misalnya pindah ke buku-buku tingkat yang lebih tinggi. Semakin banyak muridnya membaca, semakin banyak peningkatan yang mereka perhatikan yang memotivasi mereka lebih lanjut.

Seperti yang dijelaskan di bagian sebelumnya tentang persepsi program bacaan ekstensif, salah satu faktor terkuat yang secara positif mempengaruhi bacaan peserta adalah buku yang menarik dan juga mudah tersedia graded readers sebagai bahan bacaan dalam bahasa Inggris. graded readers memotivasi peserta didik, membantu mereka memperoleh kelancaran membaca, meningkatkan kosa kata mereka, dan pengembangan pengetahuan tata bahasa. Seperti juga diidentifikasi oleh Takase (2003) dan Elley (1991), yang dinilai pembaca meningkatkan motivasi dalam membaca.

\section{KESIMPULAN}

Temuan dalam data kuantitatif menunjukkan bahwa siswa telah mengembangkan kemampuan membaca mereka. Nilai rata-rata postes secara signifikan lebih tinggi daripada pretest. Yang mengejutkan, mereka dapat membaca dan memahami keseluruhan cerita meskipun mereka tidak tahu arti dari setiap kata. Dapat 
dikatakan bahwa program membaca yang luas membantu siswa untuk meningkatkan pemahaman bacaanmereka, danmendapatkan lebih banyak kata. Jadi, dapat disimpulkan bahwa program membaca yang luas dapat meningkatkan kemampuan membaca siswa.

Seperti temuan dari Pertanyaan

Motivasi Membaca dan wawancara menunjukkan bahwa motivasi membaca telah meningkat secara signifikan. Hasil motivasi siswa mengungkapkan bahwa ERP membantu siswa dalam meningkatkan motivasi membaca mereka. Selama 10 minggu program membaca yang ekstensif, para siswa menikmati membaca dan merasa nyaman untuk membaca. Sebagai hasilnya dapat disimpulkan bahwa siswa telah puas dengan program membaca yang luas.

\section{DAFTAR RUJUKAN}

Carrell, P. L., \& Carson. J. G. (1997). Extensive and Intensive Reading in an EAP Setting, English for Specific Purposes 16: 47-60.

Chumacero, R. A., Mardones, J. G., \& Paredes, R. D. (2016). Competition pressures and academic performance in Chile. Estudios de Ecodnomfa, Volume 43 (2), pp. 217-232. Retrieved from https://scielo.conicyt.cl/pdf/ ede/v43n2/art03.pdf

Day, R. R., \& Bamford, J. (2004). Extensive Reading Activities for Teaching Language. Cambridge: Cambridge University Press.

de Burgh-Hirabe, R. (2011). Extensive reading and L2 reading motivation in Japanese as a foreign language: a case study of New Zealand high school students. Doctoral thesis. Dunedin: University of Otago. Accessed 14. 4. 2013. http://hdl.handle.net/10523/1711.

Deci, E. L., \& Ryan, R. M. (1985). Intrinsic motivation and self-determination in human behavior. New York: Plenum Press.

Elley, W. B. (1991). Acquiring literacy in a second language: The effect of book-based programs. Language Learning, 41

Forgas, J. P., Williams, K. D., \& Laham, S. M. (2005). Social motivation: Conscious and Unconscious processes. Cambridge: Cambridge University Press.

Harmer, J. (2007). The Practice of English Language Teaching (4th ed.). New York: Pearson Longman.

Hill, K. M., Fombelle, P. W., \& Sirianni, N. J. (2016). Shopping under the influence of curiosity: How retailers use mystery to drive purchase motivation. Journal of Business Research, Volume 69 (3), pp. 1028-1034. https://doi.org/10.1016/j.jbusres.2015.08.015

Holtforth, M. G. (2008). Avoidance motivation in psychological problems and psychotherapy. Psychotherapy Research, Volume 18 (2), pp. 147-159. https://doi.org/10.1080/10503300701765849

Honneth, A. (1995) Integrity and Disrespect: principles of a conception of morality based on a theory of recognition, in C.W. Wright (Ed.) The Fragmented World of the Social: essays in social and political philosophy, pp. 247-260. New York: State University of New York Press.

Huttunen, R., \& Heikkinen, H. L.T. (2004) Teaching and the dialectic of recognition Pedagogy, Culture, and Society, Volume 12 (2), pp. 163-174.https://doi.org/10.1080/14681360400200194

Jager, T. (2017). How Reading Improves Brain Function. Retrieved on 19th of March 2019, from: https:// millennialmagazine.com/2017/08/02/how-reading-improves-brain-function/

Krashen, S. D. (1996). Comic book reading, enjoyment and pleasure reading among middle school students. Journal of Reading Improvement.Vol. 33(1): 51-54.(http:/www.sdkrashen.com/content/articles/1996_ comic_bk_reading.pdf)

Krypotos, A. M., Effting, M., Kindt, M., \& Beckers. (2015). Avoidance learning: A review of theoretical models and recent developments. Front Behav Neurosci, Volume 9. doi: 10.3389/fnbeh.2015.00189

Laen, S. M, \& Paulshock, J. (2018). Increasing reading self-efficacy and reading amount in EFL learners with word-target. Reading in a Foreign Language, 30, (1), 76-91.

Martini. (2008). The implementation of extensive reading task to improve students' reading motivation at accounting department, Padang state polytechnic. Jurnal Akuntansi \& Manajemen, 3, (1), 59-72.

Mayo, J. W. (2016). Economic policy vignette: Defining “competition” for the 21 st-century telecommunication industry. Washington: Georgetown University. Retrieved from https://cbpp.georgetown.edu/sites/cbpp. georgetown.edu/files/EPV_Mayo_Defining\%20C ompetition $\% 20$ for $\% 20$ the $\% 2021$ st $\% 20$ Century $\% 20$ 
Telecommunications\%20Industry.pdf

Nishino, T. (2007). Beginning to read extensively: A case study with Mako and Fumi. Reading in a Foreign Language, 19, (2), 76-105.

Peraturan Menteri Pendidikan dan Kebudayaan Nomor 21 Tahun 2015 tentang Penumbuhan Budi Pekerti.

Peraturan Menteri Pendidikan dan Kebudayaan Nomor 54 tahun 2013 tentang Standar Kompetensi Lulusan.

Richards, J. S., \& Schmidt, R. (2010). Longman Dictionary of Language and Teaching Applied Linguistics (4th ed.). Great Britain: Pearson Education Limited.

Rymanowicz, K. (2017). Children and empathy: Reading to learn empathy. [Online]. Diakses dari: https://www. canr.msu.edu/news/children and_empathy reading to_learn _empathy. 19 Maret 2019.

Sachs, G. T. (2001). Transforming Extensive Reading Lessons. New Horizons in Education, 43, 78-90.

Santoso, S. (2014). Statistik Parametrik Konsep dan Aplikasi dengan SPSS EdisiRevisi. Jakarta: PT Elex Media Komputindo.

Sappington, J., Kinsey, K., \& Munsayac, K. (2002). Two studies of reading compliance among college students. Teaching of Psychology, 29(4), 272-274.

Sharma, A., Hoof, B. V., \& Pursel, B. (2013). An assessment of reading compliance decisions among undergraduate students. Journal of the Scholarship of Teaching and Learning, Volume 13 (4), pp. 103-123.

Sheu, S. P. H. (2003). Extensive reading with EFL learners at beginning level. TESL Reporter, 36, 8-26.

Sugihartati, R. (2010). Membaca, Gaya Hidup dan Kapitalisme: Kajian tentang Reading forPleasure dari perspektif Cultural Studies. Yogyakarta: Graha Ilmu.

Takase, A. (2003). The effects of extensive reading on the motivation of Japanese high school students. Unpublished doctoral dissertation, Temple University, Osaka, Japan.

Torres, K. (2010). Factors that influence students' motivation to read across grade levels. [Thesis]. Diaskses dari: https://core.ac.uk/download/pdf/48615309.pdf.

Trombetta, S. (2017). Why Reading Is The Best Workout For Your Brain. [Online]. Diakses dari: https://www. bustle.com/p/why-reading-is-the-best-workout-for-your-brain-57441. 19 Maret 2019.

Usherwood, B., \& Toyne, J. (2002). The Value and Impact of Reading ImaginativeLiterature. Journal of Librarianship and Information Science. Vol. 34(1), 33-41.

Wang, J. H., \& Guthrie, J. T. (2011). Modeling the effects of intrinsic motivation, extrinsic motivation, amount of reading, and past reading achievement on text comprehension between U.S. and Chinese students. Reading Research Quarterly. Vol. 39(2):162-186.

Wigfield, A., \& Guthrie, J. T. (1997). Relations of children's motivation for reading to the amount and breadth or their reading. Journal of Educational Psychology, 89(3), 420-432. 